\title{
TOXICITY OF CERTAIN INSECTICIDES IN LABORATORY AGAINST COTTON LEAFWORM, SPODOPTERA LITTORALIS (BIOSD.)
}

\author{
BAYOUMI, O. CH. A. ${ }^{1}$, S. A. AREF ${ }^{2}$ AND HEBA A. B. SOLIMAN ${ }^{2}$
}

1. Faculty of Agriculture, Kafrelsheikh University

2. Plant Protection Research Institute, ARC, Dokki, Giza

(Manuscript received 13 July 2008)

\begin{abstract}
The effects of some compounds (diflubenzuron, lambdacyhalothrin and profenofos) were tested against $2^{\text {nd }}$ and $4^{\text {th }}$ instars larvae of cotton leafworm. The obtained $\mathrm{LC}_{50}$ 's were $0.26,1.38$ and $2.65 \mathrm{ppm}$ against $2^{\text {nd }}$ instar larvae. While, it gave $11.39,12.44$ and $14.40 \mathrm{ppm}$ in case of the $4^{\text {th }}$ instar larvae. Also, the effects of $B$. thuringiensis and lettuce oil extract were tested against the $2^{\text {nd }}$ instar larvae showing $\mathrm{LC}_{50}$ 's of $1.93 \times 10^{4} \mathrm{ppm}$ and $3.64 \times 10^{4} \mathrm{ppm}$, respectively.

Addition of lettuce oil extract to profenofos increased the percentage mortality which were $(86.6 \%$ or $73.3 \%)$ for $\mathrm{LC}_{50}$ or $\mathrm{LC}_{25}$, respectively. When lambda-cyhalothrin was mixed with lettuce oil extract it showed an antagonistic effect. The mortality percentages were $(26.6 \%$ or $8.3 \%)$ with $\mathrm{LC}_{50}$ or $\mathrm{LC}_{25}$, respectively.

The $\mathrm{LC}_{50}$ of lettuce oil extract was mixed for 48 hours with $\left(\mathrm{LC}_{50}\right.$ or $\left.\mathrm{LC}_{25}\right)$ of $B$. thuringiensis or with diflubenzuron. The obtained results showed an increase in the mortality percent recorded after 48 hours of treatment in comparison with control. The obtained percentages of increase were $(83.3 \%$ or $66.6 \%)$ for B. thuringiensis and $(80 \%$ or $65 \%)$ for diflubenzuron, respectively.
\end{abstract}

\section{INTRODUCTION}

Cotton is considerd one of the major economic crops in Egypt. Through cotton growth season, it is attack by many pests, from the seedling state to harvest causing different degrees and types of damage. Amongst the cotton leafworm, Spodoptera littoralis (Boisd.).

Attention was therefore paid to control insects using different chemical methods (IGR compounds, biotic insecticides, oil extract and conventional methods) which are considered nowadays as mainly elements for IPM programs, hence reduced the environmental pollution and the hazard to huminity. El-Gemeiy 1983 evaluated the efficiency of B.t (using Dipel-2x) after controlling bollworms in cotton fields, Knowles et al ., 1986 found that the B. t. more effective than conventional insecticides and Salama et al ., 1984 evaluated several such combination against S. littoralis. (Biosd. ) and found that all pyrethroids and most organophosphates tested potentiated the activity of B.t . they suggested the applications of pyrethroids with B.t. may be a safe and effective means for controlling $S$. Littoralis. . 
This work mainly aimed to throw the light on the insecticidal and biological activities of various chemical and biological agents, which represented some integrated pest program components such as IGR's, B. thuringiensis, oil extracts and conventional insecticides. These compounds were tested either individual or in combined with lettuce oil extract using different rates of application against cotton leafworm.

\section{MATERIALS AND METHODS}

\section{Chemical tested:( Insecticides)}

1.1. Organophosphorus insecticides: Profenofos (Acron, $72 \%$ E.C.)

1.2. Pyrethroids: Lambda-cyhalothrin (Lambda, $5 \%$ E.C.)

1.3. Insect growth regulators (I.G.R.): Diflubenzuron (Demeron, $10 \%$ E.C.)

2. Bacterial insecticides (biocide): Bacillus thuringiensis.

Agerin, 6.5\% WP (contain $32000 \mathrm{IU} / \mathrm{mg}$ ).

\section{Plant extracts: Oil extraction from lettuce leaves}

50 gram of untreated lettuce plants Lactuca sativa (L.) were collected from Kafr El-Sheikh Farm then washed with distilled water to clean it from different soil wastes. Leaves were then kept at room temperature to dryness.

Dried leaves were cut into small parts and then were extracted with petroleum ether in a Blender at high speed and at room temperature. The petroleum ether extract was then filtered on a filter glass G4. The residues on the filter glass were washed twice with $50 \mathrm{ml}$ of petroleum ether. The filtrates were combined and evaporated into rotatory evaporator to dryness. The crude oil extract was cleaned on a chromatographic column using a granulated florisil (60-80 mesh) and eluted with a mixture of acetone-petroleum ether (1: $3 \mathrm{v}: \mathrm{v})$. The elution were combined and evaporated in a vacuum rotatory evaporator to eliminate the solvents used in the above steps. The obtained oil was used in different experimental tests.

\section{Susceptible strain of cotton leafworm}

A susceptible strain of cotton leafworm, Spodoptera littoralis (Boisd.) were obtained from Agriculture Research Center at Kafr El-Sheikh it was reared for several generation on castor bean oil leaves (Ricinus communis) under laboratory condition of $26 \pm 2^{\circ} \mathrm{C}$ and $65 \pm 5 \% \mathrm{RH}$.

5. Laboratory evaluation 


\section{Laboratory evaluation}

\section{Toxicity bioassays of some organic compounds activity against cotton} leafworm larvae, Spodoptera littoralis

\section{Toxicity tests}

The activities of profenofos, lambda-cyhalothrin and difluobenzuron were assessed against $2^{\text {nd }}$ and $4^{\text {th }}$ instar larvae, while with lettuce oil extract and $B$. thuringiensis (agerin) $2^{\text {nd }}$ instar larvae were only evaluated. Larvae were starved for 46 hours before treatment (Merdan, 1968).

Serial aqueous concentration were prepared with of the range of $0.3-80 \mathrm{ppm}$ for (profenofos), 0.3-50 ppm for (lambda-cyhalothrin), 0.01-60 ppm for (diflubenzuron), $(0.05-4) \times 10^{4} \mathrm{ppm}$ for (B. thuringiensis) and (1-4) $\times 10^{4} \mathrm{ppm}$ for (lettuce oil extract).

Disks of castor bean oil leaves $(9 \mathrm{~cm}$ diameter) were dipped in the tested concentration for 10 seconds left to dry and offered to the larvae which were placed into plastic cups (each $6 \times 7.5 \mathrm{~cm}$ dimension) at room temperature (20 larvae each). Each treatment was replicated three times in addition to control (check), in these experiments two types of control were made. The first was made by mixing acetone with distilled water by the same ratio of tested treatment, the second was done by using distilled water only. Mortality was recoded after 24 hours exposure period for profenofos and lambda-cyhalothrin.

For $B$. thuringiensis (agerin), diflubenzuron and lettuce oil extract larvae were fed on treated leaves for 48 hours. Then treated larvae were offered untreated leaves.Mortality were estimated up to 5 days. Mortality was corrected according to Abbott's formula (1925), and data were statistically analyzed by probit analysis method of Finney, 1971.

\section{Joint action effect}

Joint action of various organic compounds with lettuce oil extract were tested using dipping technique. The calculated $\mathrm{LC}_{50}$ of lettuce oil extract was mixed with the $\mathrm{LC}_{25}$ or $\mathrm{LC}_{50}$ of different organic compounds tested against the $2^{\text {nd }}$ instar larvae. Check replicates using untreated castor bean oil leaves, results were recorded after 24 hrs and 48 hrs of treatments.

\section{RESULTS AND DISCUSSION}

The toxicity of profenofos, lambda-cyhalothrin and diflubenzuron (I.G.R) affected $2^{\text {nd }}$ and $4^{\text {th }}$ instars larvae, while $B$. thuringiensis (agerin) and lettuce oil extract affected the $2^{\text {nd }}$ instar larvae and did not have any effect on the $4^{\text {th }}$ instar larvae under laboratory conditions, using dipping technique. 
Results in Table (1) and Figs. $(1,2)$ showed the obtained $L_{50}$ 's with the $2^{\text {nd }}$ instars larvae with the tested compounds lambda-cyhalothrin and profenofos were 1.38 and 2.65 p.p.m, respectively. These results showed that after $24 \mathrm{hrs}$, lambdacyhalothrin was the most potent compounds followed by profenofos.

Table 1. Effect of various organic compounds against $2^{\text {nd }}$ instar larvae of Spodoptera littoralis under controlled conditions.

\begin{tabular}{|l|c|cc|c|}
\hline \multicolumn{1}{|c|}{ Organic compounds } & $\begin{array}{c}\mathrm{LC}_{50} \\
(\mathrm{ppm})\end{array}$ & \multicolumn{2}{c|}{$\begin{array}{c}\text { Confidence } \\
\text { limit at 95\% }\end{array}$} & Slope \\
\hline Lettuce oil extract* & $3.64 \times 10^{4}$ & $\left(3.18 \times 10^{4}\right.$ & $\left.3.88 \times 10^{4}\right)$ & 0.65 \\
\hline Bacillus thuringiensis (agerin)* & $1.93 \times 10^{4}$ & $\left(0.98 \times 10^{4}\right.$ & $\left.6.60 \times 10^{4}\right)$ & 0.46 \\
\hline Profenofos** & 2.65 & $(1.93$ & $4.81)$ & 0.46 \\
\hline Lambda-cyhalothrin** & 1.38 & $(1.20$ & $1.62)$ & 0.32 \\
\hline Diflubenzuron (I.G.R.) & 0.26 & $(0.21$ & $0.34)$ & 0.13 \\
\hline
\end{tabular}

* Data were recorded after 5 days of treatment

** Data were recorded after 24 hours of treatment

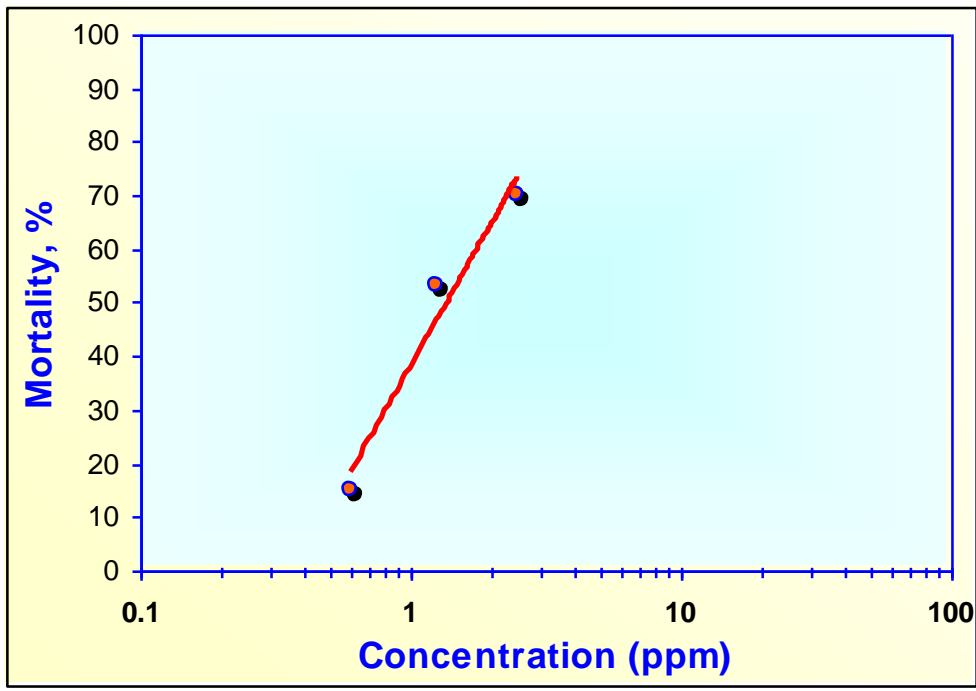

Fig. 1. Log-dosage probit regression line of lambda-cyhalothrin against $2^{\text {nd }}$ instar larvae of Spodoptera littoralis after 24 hrs of treatment 


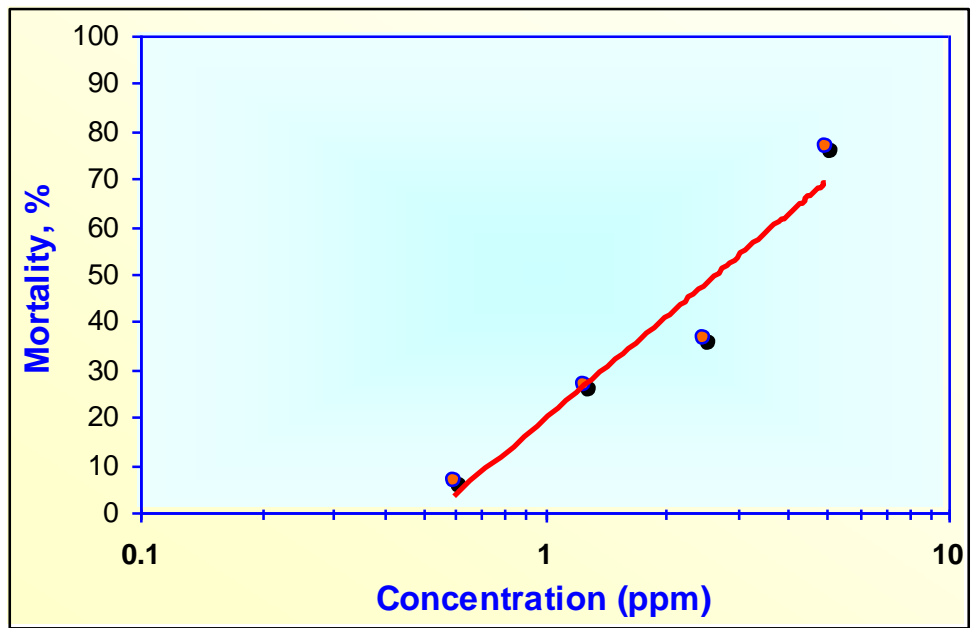

Fig. 2. Log-dosage probit regression line of profenofos against 2 nd instar larvae of Spodoptera littoralis after 24 hrs of treatment

In the other hand after 5 days results in Table (1) and Figs. $(3,4,5)$ showed that, diflubenzuron (I.G.R.) was more toxic toward the $2^{\text {nd }}$ instar larvae of $S$. littoralis than the other tested compounds ( $B$. thuringiensis (agerin) and lettuce oil extract). The obtained $\mathrm{LC}_{50}$ 's were $0.26,1.93 \times 10^{4}$ and $3.64 \times 10^{4}$ p.p.m, respectively.

Table $(2)$ and Figs. $(6,7,8)$ showed toxicity tests were made against the $4^{\text {th }}$ instars larvae with the diflubenzuron (I.G.R). LC 50 obtained after 5 days of treatment it was $11.39 \mathrm{ppm}$. From the results it was evident that diflubenzuron (I.G.R) was more effective against the $2^{\text {nd }}$ instar larvae comparing with that obtained with the $4^{\text {th }}$ instar larvae. At the same time the two pesticides lambda-cyahlothrin and profenofos were tested for their effectiveness against the $4^{\text {th }}$ instar larvae. The obtained results after 24 hrs showed that lambda-cyhalothrin was more effective than profenofos $L_{50}$ 's were 12.44 and 14.40 p.p.m., respectively.

Our results are confirmed with those obtained by El-Lakwah (1998) who found fenvalerate was the most toxic followed by profenofos. Also, El-Maghraby et al. (1999) who found that IGR's at the recommended rate were as good as tested insecticide. Atallah et al. (2001), who found that $2^{\text {nd }}$ instars larvae were the most susceptible to Agerin. The total \% mortality was higher in case of S. littoralis (39\%). Abo El-Ftooh (2004) who found profenofos was more effective against $S$. littoralis than the isolated bacteria and two bio-insecticides. 
Table 2. Effect of various insecticides compounds against $4^{\text {th }}$ instar larvae of Spodoptera littoralis under laboratory condition.

\begin{tabular}{|l|c|cc|c|}
\hline \multicolumn{1}{|c|}{ Organic compounds } & $\begin{array}{c}\mathrm{LC}_{50} \\
(\mathrm{ppm})\end{array}$ & \multicolumn{2}{|c|}{$\begin{array}{c}\text { Confidence } \\
\text { limit at 95\% }\end{array}$} & Slope \\
\hline Profenofos * & 14.40 & $(12.44$ & $16.76)$ & 0.24 \\
\hline Lambda-cyhalothrin* & 12.44 & $(10.74$ & $14.63)$ & 0.30 \\
\hline Diflubenzuron (I.G.R.)* & 11.39 & $(9.57$ & $14.38)$ & 0.24 \\
\hline
\end{tabular}

* Data were recorded after 5 days of treatment

** Data were recorded after 120 hours of treatment

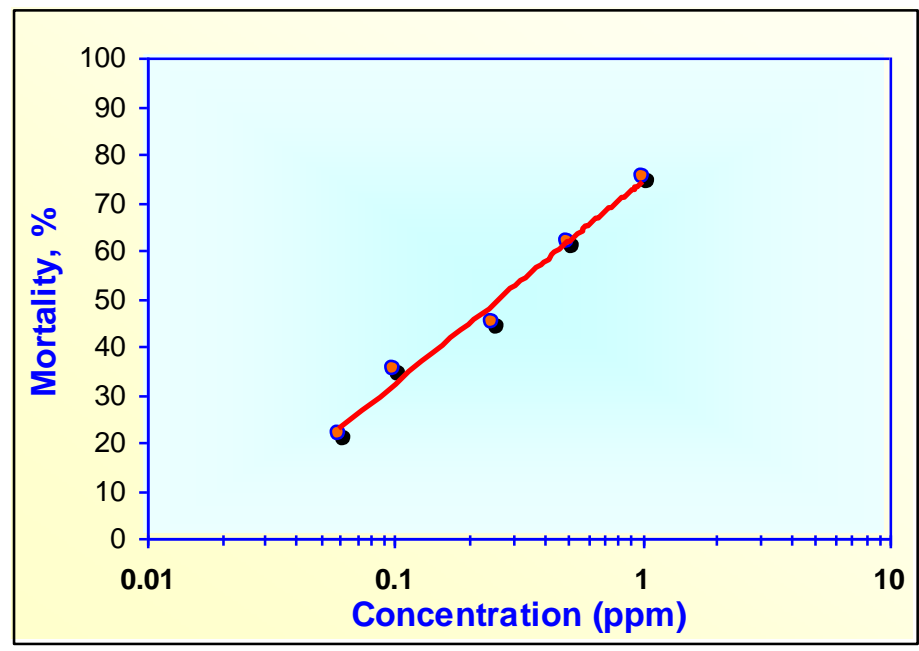

Fig. 3. Log-dosage probit regression line of diflubenzuron against 2 nd instar larvae of Spodoptera littoralis after 120 hrs of treatment

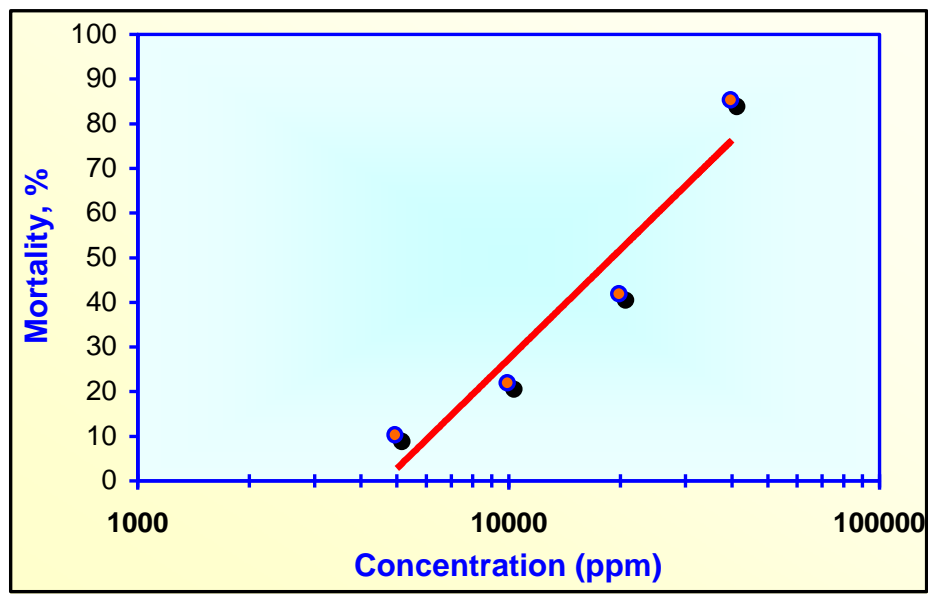

Fig. 4. Log-dosage probit regression line of $B$. thuringiensis against $2^{\text {nd }}$ instar larvae of Spodoptera littoralis after 120 hrs of treatment 


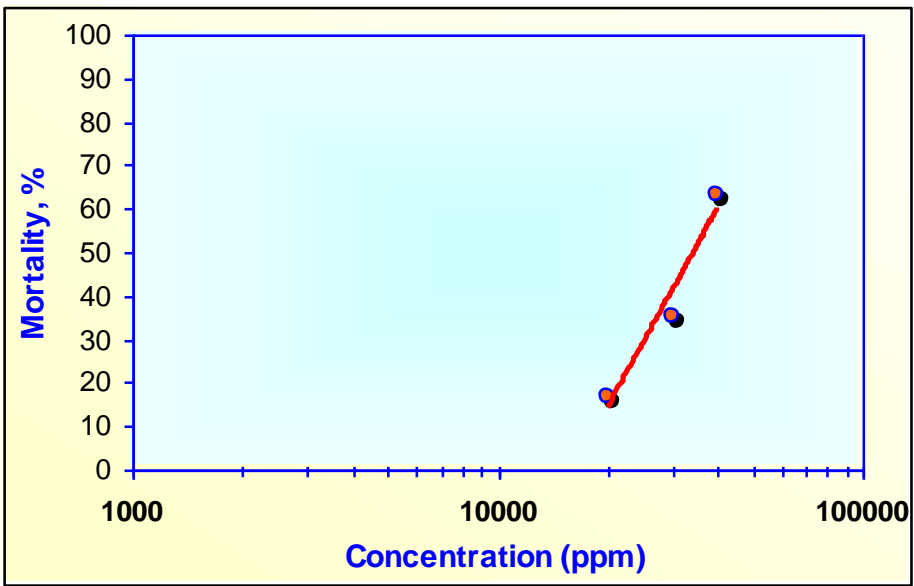

Fig. 5. Log-dosage probit regression line of lettuce oil against 2 nd instar larvae of Spodoptera littoralis after 120 hrs of treatment.

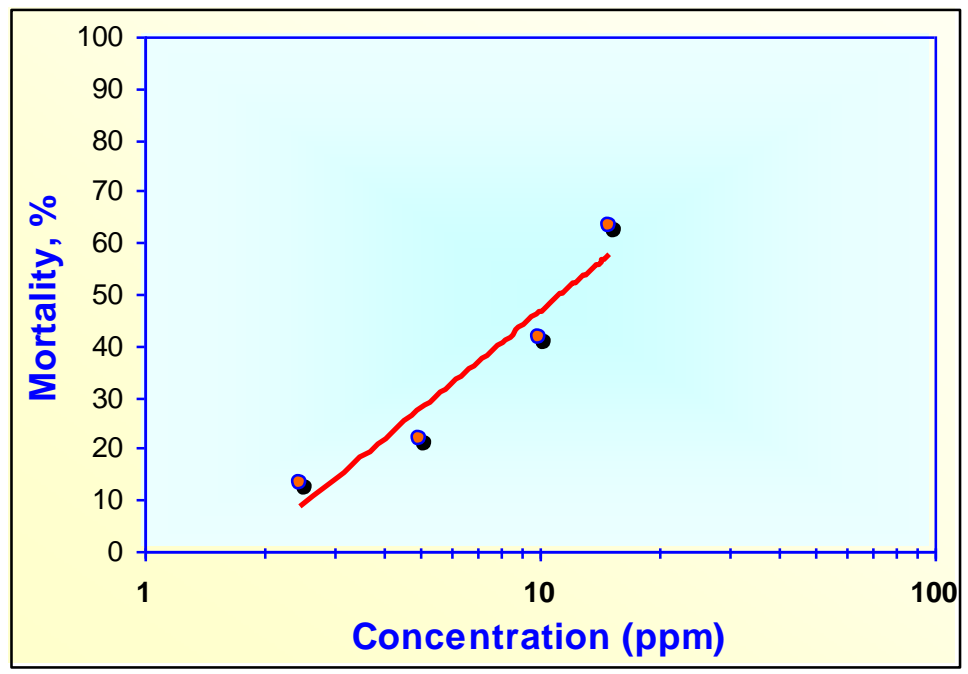

Fig. 6. Log-dosage probit regression line of diflubenzuron against 4th instar larvae of Spodoptera littoralis after $120 \mathrm{hrs}$ of treatment

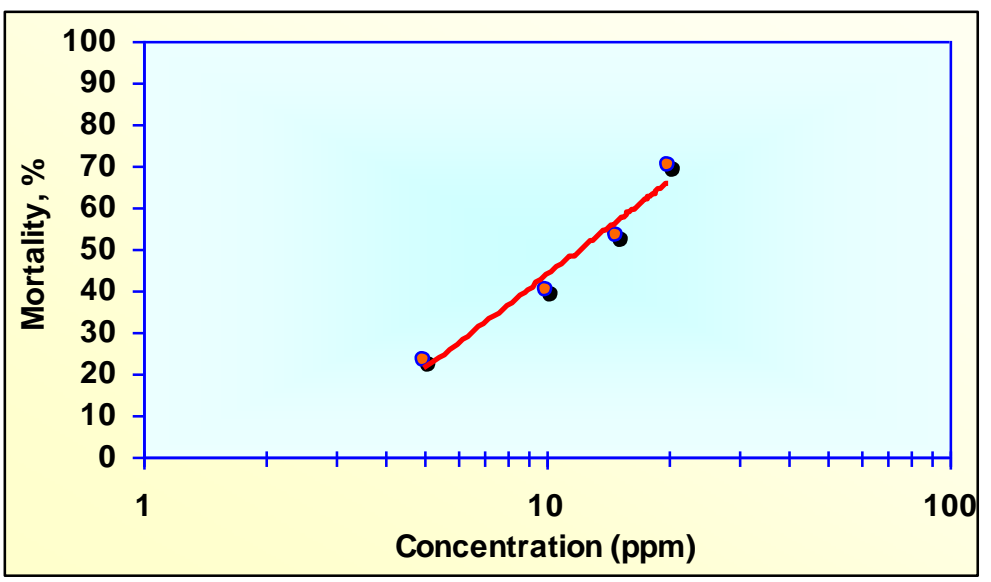

Fig. 7. Log-dosage probit regression line of lambda cyhalothrin against 4th instar larvae of Spodoptera littoralis after 24 hrs of treatment 


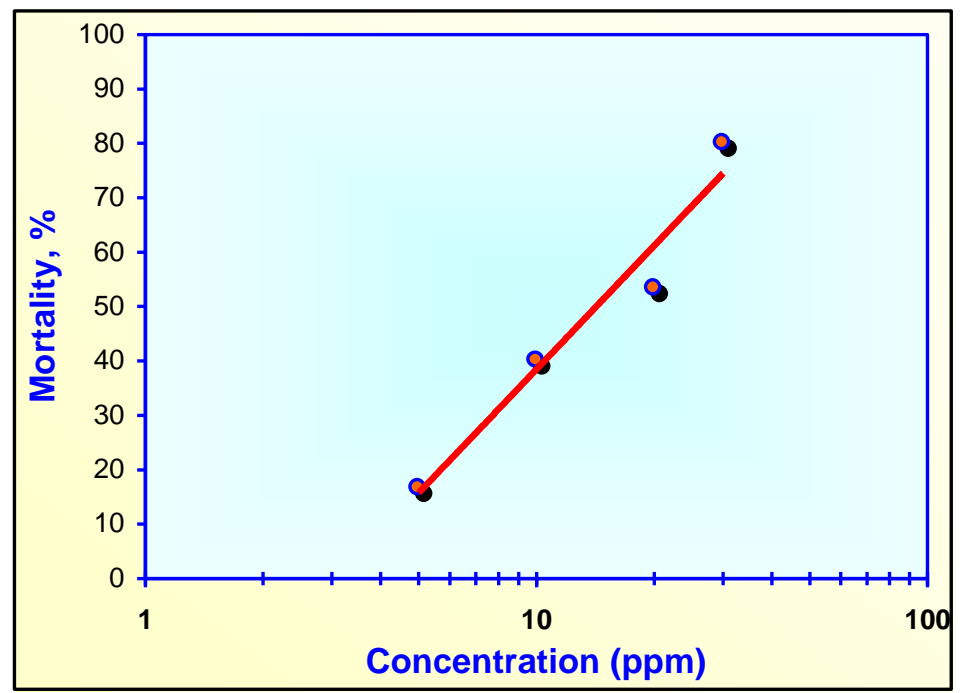

Fig. 8. Log-dosage probit regression line of profenofos against 4th instar larvae of Spodoptera littoralis after $24 \mathrm{hrs}$ of treatment.

\section{Joint action effects}

The binary mixture between the $\mathrm{LC}_{50}$ of lettuce oil extract with the ( $\mathrm{LC}_{50}$ or $\mathrm{LC}_{25}$ ) of lambda-cyhalothrin or profenofos after 24 hrs were tested against the $2^{\text {nd }}$ instars larvae of S. littorals, using dipping technique. Results listed in Table (3) indicated that addition of lettuce oil extract to profenofos increased the percentage mortality which were $(86.6 \%$ or $73.3 \%)$ for $\mathrm{LC}_{50}$ or $\mathrm{LC}_{25}$, respectively. While, with lambda-cyhalothrin mixed with lettuce oil extract showed an antagonistic effect. The mortality percentages were $(26.6 \%$ or $8.3 \%)$ with $\mathrm{LC}_{50}$ or $\mathrm{LC}_{25}$, respectively.

Also, the binary mixture between lettuce oil extract with $B$. thuringiensis or diflubenzuron at the levels of $\mathrm{LC}_{50}$ or $\mathrm{LC}_{25}$ were tested against $2^{\text {nd }}$ instar larvae of $S$. littoralis. Data recorded after 24 and 48 hrs of treatment are shown (Table 4). The obtained results indicated that there is no effect after $24 \mathrm{hrs}$ of treatment while, after 48 hrs results showed that their synergistic effects were $(83.3 \%$ or $66.6 \%)$ for $B$. thuringiensis and ( $80 \%$ or $65 \%$ ) for diflubenzuron, respectively.

Table 3. Joint action effect of lettuce oil extract at the concentration of $\mathrm{LC}_{50}$ mixed with $\mathrm{LC}_{25}$ or $\mathrm{LC}_{50}$ of Lambda-cyhalothrin or Profenofos against the $2^{\text {nd }}$ larvae of Spodoptera littoralis after 24hours of treatment.

\begin{tabular}{|c|c|c|c|c|}
\hline \multirow{2}{*}{ Lettuce oil extract } & \multicolumn{2}{|c|}{ Lambda-cyhalothrin } & \multicolumn{2}{|c|}{ Profenofos } \\
\cline { 2 - 5 } $\mathrm{LC}_{50}$ & $\mathrm{LC}_{25}$ & $\mathrm{LC}_{50}$ & $\mathrm{LC}_{25}$ & $\mathrm{LC}_{50}$ \\
$\left(3.64 \times 10^{4} \mathrm{ppm}\right)$ & $(0.65 \mathrm{ppm})$ & $(1.38 \mathrm{ppm})$ & $(1.17 \mathrm{ppm})$ & $(2.65 \mathrm{ppm})$ \\
\hline $\begin{array}{c}\text { Mortality (\%) after } \\
24 \text { hours }\end{array}$ & 8.3 & 26.6 & 73.3 & 86.6 \\
\hline
\end{tabular}


Table 4. Joint action effect of lettuce oil extract at the concentration of $\mathrm{LC}_{50}$ mixed with $\mathrm{LC}_{25}$ or $\mathrm{LC}_{50}$ of $\mathrm{B}$. thuringiensis or Diflubenzuron against the 2 nd larvae of Spodoptera littoralis after $48 \mathrm{hrs}$ of treatment.

\begin{tabular}{|c|c|c|c|c|}
\hline \multirow{2}{*}{$\begin{array}{c}\text { Lettuce oil extract } \\
\mathrm{LC}_{50}\end{array}$} & \multicolumn{2}{|c|}{ B. thuringiensis } & \multicolumn{2}{c|}{ Diflubenzuron } \\
\cline { 2 - 5 }$\left(3.64 \times 10^{4} \mathrm{ppm}\right)$ & $\left(9.5 \times 10^{3} \mathrm{ppm}\right)$ & $\left(19.3 \times 10^{3} \mathrm{ppm}\right)$ & $(0.07 \mathrm{ppm})$ & $\mathrm{LC}_{25}$ \\
\hline $\begin{array}{c}\text { Mortality (\%) after } \\
48 \text { hours }\end{array}$ & 66.6 & 83.3 & 65 & 80 \\
\hline
\end{tabular}

\section{REFERENCES}

1. Abbott, W. S. 1925. A method of computing the effectiveness of an insecticide. J. Econ. Entomol., 18: 625-627.

2. Abo El-Ftooh, A. A. 2004. Efficiency of estimation of isolated bacteria Bacillus thuringiensis entomocidus against cotton leafworm (Spodoptera littoralis Boisd.) infesting sugar beet in comparison with two commercial bio-insecticide and insecticide profenofos. Annals. Agric. Sci. Moshtohor, 42(3): 1405-1413.

3. Atallah, F. A., A. A. El-Zoghby and M. A. Eweis. 2001. Susceptibility of three lepidopterous pests, Sesamia cretica (Led.), Spodoptera littoralis (Boisd.) and Agrotis ipsilon (Hubn.) to the bacterial biocide "Agerin". Egypt. J. Biological Pest Control, 11(1/2): 45-49.

4. El-Gemiey, M. El-Hyat. 1983. Microbial control of cotton bollworms. Ph. D. Thesis, Fac. Of Agric. Moshtohor, Zagazig University, 1983.

5. El-Lakwah, F. A., A. A. Darwish, H. A. Abdel-Wahab and H. S. Shaalan. 1998. Susceptibility of cotton leafworm Spodoptera littoralis (Boisd.) to neemazol and some biological observations resulted from larval treatment. Annals Agric. Sci., Moshtohor, 36(2): 1157-1170.

6. El-Maghraby, H.M., M.H. El-Khawalka, M.A. El-Bessomy and H.I.H. Omar (1999). Effect of three IGR's compared with chemical insecticides against cotton leafworm, Spodoptera littoralis (Boisd.) infesting tomato plants. $2^{\text {nd }}$ Int. Conf. of Pest Control, Mansoura, Egypt, Spet.

7. Finney, D. J. 1971. Probit Analysis A Statistical Treatment of the Sigmoid Response Curve, $7^{\text {th }}$ Ed., Cambridge Univ. Press. Cambridge, England.

8. Knowles, B. H., P. H. Francis and D. J. Ellar. 1986. Structurally related Bacillus thuringiensis Delta-Endotoxins display major differences insecticidal activity in vivo and in vitro. J. Cell. Sci. 84..221-236 .

9. Merdan, A. I. 1968. Studies on the effect of certain chemical entomopathogens on some cotton worms in Egypt. M.Sc. Thesis, Fac. Sci., Cairo Univ.

10. Salama, S. S., M. S. FODA, F. N. ZAKI, S. MOAWAD. 1984. Potency of combinations of Bacillus thuringiensis and chemical insecticides on spodoptera littoralis (lePidoptera: noctuidae ) .J. Econ. Entomol. 77,885-890. 


\section{سمية بعض المبيدات الحشرية ضد دودة ورق القطن \\ عثمان شكرى عبده بيومى' ، صفوت عبد السلام عارف ' ،

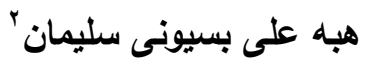

ا ـ كلبة الزراعة . جامعة كفرالثيخ r ـ معهُ بحوث وقابة النباتات - مركز البحوث الزراعية - الدقى - جبيزة .

اختبرت فاعلية مركبات الدايفلوبنزيورون (منظم نمو) ، لمبادا سيهالوثرين (بيروثرويد)

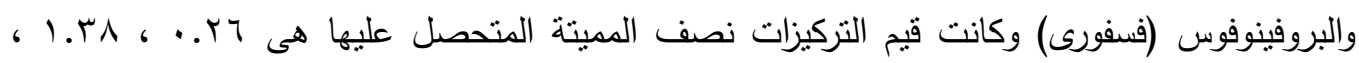

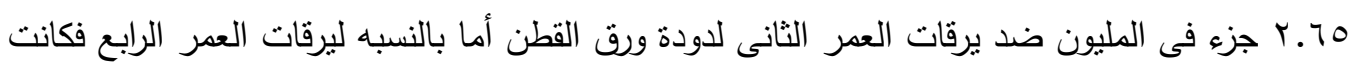

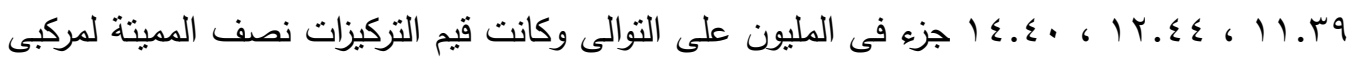

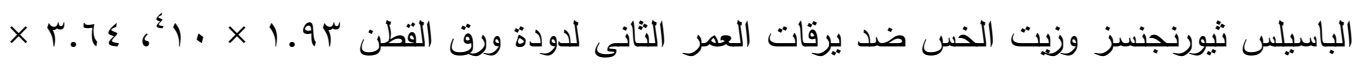
• أ جزء فى المليون على التوالى.

نم خلط LCC لزيت الخس مع (LC25, LC ) ، للمبيدين البروفينوفوس أو لمبادا ـ سيهالوثرين لمدة

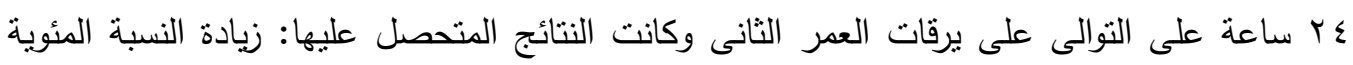

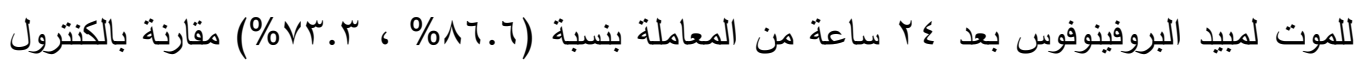

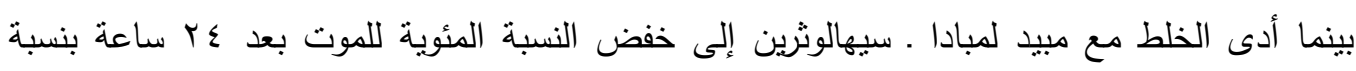

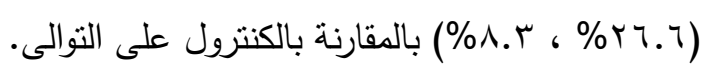

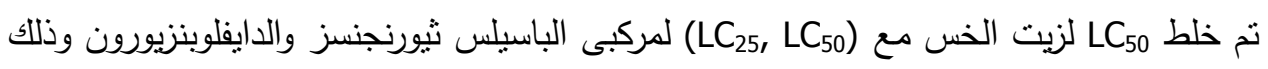

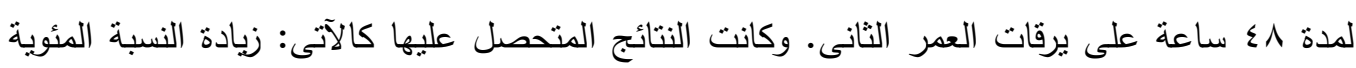

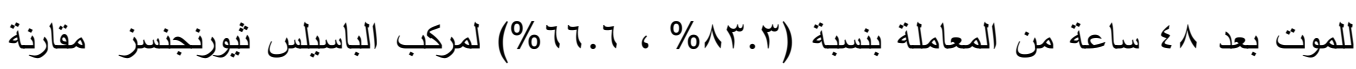

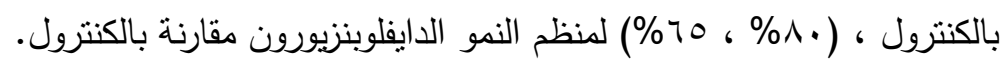

